\title{
Upaya Pencegahan Seks Bebas dan Pemahaman Reproduksi Sehat pada Remaja
}

\author{
Eka Sarofah Ningsih*, Ida Susila, Oktavia Dian Safitri \\ Prodi DIII Kebidanan, Universitas Islam Lamongan \\ *Correspondent Author: ekasnhp@gmail.com
}

\begin{abstract}
ABSTRAK
Remaja wajib tahu tentang kesehatan reproduksi sehat agar memiliki memiliki infromasi yang benar mengenai proses reproduksi serta berbagai faktor masalah yang terjadi. Tujuan pendidikan kesehatan reproduksi pada remaja yaitu remaja bisa mengetahui pentingnya kesehatan reproduksi remaja pada masa pubertas. dampak negatif, mengetahui berbagai penyakit pada alat reproduksi serta bisa menjaga kebersihan dan kesehatan diri sendiri. Dengan mendapat informasi yang benar, diharapkan remaja memiliki sikap dan tingkah laku yang bertanggung jawab dalam proses reproduksi sehat. Metode pada pengabdian masyarakat saat ini yang digunakan adalah ceramah, diskusi dan tanya jawab. Hasil penelitian menunjukan bahwa: (1) Pemberian pemahaman kepada orang tua untuk mengatasi masalah seks bebas pada remaja (2) Upaya pencegahan seks bebas dengan pemahaman pendidikan kesehatan reproduksi serta dampak penyakit yang ditimbulkan (3) Usaha pencegahan dalam menanggulangi problema seksualitas remaja (4) Layanan informasi dalam aplikasi tentang pemahaman reproduksi sehat pada remaja.
\end{abstract}

Kata Kunci: Seks Bebas, Remaja, Reproduksi Sehat

This is an open-acces article distributed under the terms of the Creative Commons Attribution-ShareAlike 4.0 International License.

\section{PENDAHULUAN}

Pubertas mengalami perkembangan dari gonad (kelenjar seks), organ genital, dan karakteristik seks sekunder, untuk bereproduksi. Pubertas mengalami tahap perubahan fisik dari masa anak- anak menjadi masa dewasa. Pada masa remaja terdapat tiga resiko yang akan dihadapi oleh remaja, yaitu seksualitas (sex pranikah), HIV/ AIDS dan Napza (penyalahgunaan obat-obatan terlarang) yang juga akan mempengaruhi kesehatan reproduksi remaja. Dampak dari masalah kesehatan reproduksi remaja selain jasmaninya, berpengaruh juga pada kesehatan mental dan emosi, kesejahteraan sosial dan keadaan ekonomi. Dampak jangka panjang yang terjadi dalam seks bebas tidak hanya berpengaruh terhadap remaja itu sendiri, tetapi juga berpengaruh terhadap keluarga dan kehidupan di masyarakat. Pembinaan sosialisasi kesehatan reproduksi remaja untuk memberikan informasi dan pengetahuan tentang perilaku hidup sehat bagi remaja untuk mengatasi masalah yang ada. Dengan bekal pengetahuan yang memadai dan motivasi menjalankan masa remaja secara sehat dan produktif, sehingga remaja diharapkan mampu memelihara kesehatan dirinya agar dapat memasuki masa kehidupan berkeluarga dengan sistema reproduksi yang sehat.

\section{METODE}

Sasaran kegiatan pengabdian kepada masyarakat ini adalah 22 orang meliputi para remaja usia 14-21 tahun. Metode yang digunakan yaitu (1) Ceramah melaui Informasi kesehatan reproduksi adalah informasi- informasi yang berhubungan dengan anatomi dan fungsi organ reproduksi, pubertas, keperawanan dan keperjakaan, kesuburan dan kemandulan, kehamilan, kontrasepsi, aborsi, 


\section{Journal of Community Engagement in Health}

http://jceh.org

https://doi.org/10.30994/jceh.v4i2.169

ISSN: 2620-3758 (print); 2620-3766 (online)

Vol. 4 No 2. Sep 2021. Page. 280-281

serta penyakit seksual yang menular dan HIV/ AIDS. (2) Diskusi dengan Tanya jawab materi yang telah dipaparan waktu ceramah. (3) Evaluasi berkala dalam bimbingan konseling remaja.

\section{HASIL DAN PEMBAHASAN}

Pembangunan karakter anak merupakan sebuah proses yang harus dimulai sejak dini dan bahkan ketika beranjak remaja anak membutuhkan dukungan keluarga untuk terlibat dalam kehidupan reproduksi sehat. Dukungan orangtua yang paling besar tanggung jawabnya untuk memberikan aspek moral dari seksualitas bagi perkembangan anak-anak dikemudian hari. Lingkungan keluarga di rumah adalah tempat yang terbaik untuk menyampaikan informasi tentang seks kepada anakanaknya. Orang tualah yang paling mengenal sifat anak-anaknya. Orangtua pula yang mengetahui tingkat kematanganya. Informasi dan penyuluhan serta konseling perlu ditingkatkan untuk mengatasi masalah pada kesehatan reproduksi remaja. Keluarga dan masyarakat sekitar juga ikut peduli dengan kondisi remaja untuk membantu remaja jika mengalami masalah kesehatan reproduksi, dengan cara diarahkan dan dicarikan jalan keluar yang baik dengan pemecahan masalah pada tempat pelayanan kesehatan reproduksi remaja untuk mendapatkan konseling ataupun pelayanan klinis.

Layanan informasi tidak hanya sekedar memberikan informasi kepada individu, melainkan layanan ini juga memiliki tujuan dan fungsi yang tentunya akan menjadikan individu menjadi lebih baik. Beberapa metode yang biasa digunakan untuk layanan informasi antara lain (1) Ceramah, Tanya Jawab dan Diskusi (2) Media. Pelayanan bimbingan dan konseling sangat berperan penting dalam hal ini dengan memberikan layanan informasi mengenai kesehatan reproduksi pada remaja pria dan wanita yang sedang tumbuh berkembang dapat memperoleh sumber informasi yang benar.

\section{KESIMPULAN}

Pengabdian masyarakat ini banyak memberikan manfaat bagi seluruh peserta remaja dan juga narasumber. Hasilnya peningkatan pengetahuan tentang kesehatan reproduksi sehat pada remaja dan sek bebas yang terjadi di masa remaja sekarang. Setelah memahami dan peningkatan pengetahuan tersebut diharapkan ada kesadaran akan pentingya menjaga kesehatan reproduksi sehat pada remaja serta bisa mengaplikasi ilmu yang diterimanya dalam kehidupan sehari-hari serta bisa menjadi transfer knowledge pada remaja lainnya.

\section{REFERENSI}

Abduh, Bilif. 2011 . Ibu Itu Sungguh Ajaib. Yogyakarta: Transmedia

Kemenkes RI. 2013. Aku bangga aku tahu: petunjuk teknis pembinaan dan penyuluhan kampanye pencegahan HIV-AIDS “aku bangga aku tahu”. Jakarta: Kemenkes RI

Miswanto. 2014. Pentingnya Pendidikan Kesehatan Reproduksi dan Seksualitas Pada Remaja (Vol 3, No. 2). Jurnal Studi Pemuda

Nasution, S.L. 2012. Pengaruh Pengetahuan Tentang Kesehatan Reproduksi Remaja terhadap Perilaku Seksual Pranikah Remaja di Indonesia (Vol. 15, No. 1). Widyariset Susanto, R.C., dan Made, M, G.A. 2013. Penyakit kulit dan kelamin. Yogyakarta: Nuha Medika

Syafrudin, D.A.D., dan Delmaifanis. 2011. Himpunan penyuluhan kesehatan pada remaja, keluarga, lansia dan masyarakat. Jakarta: Trans Info Media (TIM) 